DOI 10.18551/rjoas.2019-06.38

\title{
TAX PLANNING AS A TAX AVOIDANCE STEP IN INDONESIA
}

\author{
Sari Ririn Puspita \\ Faculty of Business and Economics, University of Airlangga, Indonesia \\ E-mail: ririn49291@gmail.com
}

\begin{abstract}
Tax planning is the first step in tax management. Tax management itself is a means to fulfill tax obligations correctly, but the amount of tax paid can be reduced to a minimum to obtain the expected profit and liquidity. Tax planning aggressive ones are very dangerous and can erode the tax base. The taxation system in Indonesia that is now being used is a development of the system that was originally carried out since the development of the manufacturing industry. For legal certainty for both taxpayers and the government, provisions regarding tax planning, tax avoidance, and anti tax avoidance in the form of Specific Avoidance Rule (SAAR) and General Anti Avoidance Rule (GAAR) must be clearly and detailed in the provisions of legislation - tax invitations, both for formal provisions, which are related to sanctions, as well as in the material provisions.
\end{abstract}

\section{KEY WORDS}

Tax, planning, public service, provision, profit.

In order to improve efficiency and competitiveness, companies must reduce costs as optimally as possible. Similarly, the obligation to pay taxes, because tax costs will reduce profit after tax, the rate of return, and cash flow (Damayanti, 2009: 15). Cao and Xu (2009) stated that, a company has a large space to make tax efficiency on their income tax because corporate income tax occupies an important status in paying taxes.

Suandy (2011: 8) states, managers must reduce tax costs as optimally as possible to improve the efficiency and competitiveness of companies by managing tax obligations. Management of taxationobligations is carried out by conducting a tax management which is part of financial management, so that the objectives of tax management must be in line with the objectives of financial management, namely obtaining adequate liquidity and profit.

Minimizing the amount of tax burden can be done in various ways both tax avoidance and tax evasion. Tax avoidance is a term in tax planning that is used to signify that taxpayers have used legitimate schemes to reduce their tax obligations (Potas, 1993). According to Logue (in McLaren 2008), simple tax avoidance can be defined as regulating all matters of corporate taxation to minimize taxes in a way that is consistent with the law, while tax evasion involves an intentional element of breaking the law in payment tax. According to Adawiah (2011), to implement tax avoidance properly and not be trapped into a tax evasion, it is necessary to have a tax management.

Tax Planning is the first step in tax management. Tax management itself is a means to fulfill obligations taxation correctly, but the amount of tax paid can be reduced. The Director General of Taxes once revealed that Tax Planning for the company is considered correct insofar as it does not violate tax regulations applicable. Because it must be admitted that there is no one in the Tax Law which prohibits tax planning.

\section{LITERATURE REVIEW}

According to Zain (2003: 12), understanding economically (tax as transfer of resources from the private sector to the government sector) or understanding juridically (tax is a contribution that can be imposed).

According to Ahmadi (2006: 6), states that: "Tax is a coercive contributions from individuals to the government to finance expenses related to the interests of the public without it can be shown that there are special advantages to it". 
According to R. Santoso Brotodiharjo, in the book Introduction to Tax Law (1993: 2), where is tax considered as an obligation to surrender a portion of assets to cash the state is caused by a situation, an event and an act that gives certain position, but not as a punishment, according to the rules determined by the government and can be forced, but there is no reciprocal service from the state directly, to maintain public welfare.

According to Zain (2003: 54), tax planning is a related action with the consequences of the potential tax, which is emphasized in control every transaction that has tax consequences. The goal adal ahhow such control can minimize the amount of tax will be given to the government through what is called tax avoidance and tax evasion which is a fiscal crime. Zain (2003: 47) describes tax management as a means for fulfill taxation obligations correctly but the amount of tax paid can be reduced as low as possible to obtain profit and liquidity expected. Theoretically, tax planning is part of functions tax management consisting of: planning, implementation and control. Tax Planning according to Susan (2003: 303 ) is "Arrangement of a person 's business and / or private affairs in order to minimize tax liability".

Eskew (2008: 762) mentions Tax Planning is "The practice of evaluating the tax effects of integrated actions or transactions, while Spitz (2003: 1) states that "Tax Planning is the process of taking intoconsideration of all revelant tax factors, in light of the material non tax factors, for the purpose of determining": whether; and if so; how; and with whom, to enter into and conduct transactions, operations and relationships, with the object of keeping the tax on events and persons as low as possible while attaining the desired business, personal and other objectives. Tax Planning is a systematic analysis of deferring tax options aimed at the minimization of tax liability in current and future tax periods.

Suandy (2003: 119) mentions forms of tax planning consists of:

Taking advantage of a wide choice of legal form (legal entity) that is appropriate for the needs and type of business. When viewed from Sometimes the selection of taxation perspective of the legal entity(legal entities) individual forms, firms and partnerships are forms that are more profitable than limited liability companies that hold individual or entity shares but less than $25 \%$, will resulttax on company income is imposed twice, at the time income is obtained by the company and at the time of income distributed as dividends to individual shareholders or entities which is less than $25 \%$.

Choose the location of the company to be established. Generally the government provide a kind of tax incentives / tax facilities especially for certain regions, a lot of income tax deductions are given as referred to in Article 26 of Law No. 17 of 2000. D it is also given facilities such as shrinkage and amortization accelerated, longer compensation for losses. For example: company expanding its business by establishing a new company in the area remote in eastern Indonesia. Therefore the area has economic potential that is feasible to develop but difficult to reach, then the government provides some relief in taxes such as permission to reduce the fringe benefit of gross income as regulated in SE-29 / Pj.4 / 1995 June 5, 1995.

Take maximum profit or as much as possible from various exceptions, deductions or deductions for taxable income taxes allowed by law.

Establish a company in a business company so that regulated regarding the use of the most favorable tax rates between each business entity. This can be done considering that many countries including Indonesia regulate that inter-corporate dividend distribution is not subject to tax.

Establishing a company is a profit center and some are only functions as a cost center. From this, benefits can be obtained by spreading income into income from several taxpayers in one group as well as costs so they can gains obtained from tax shifting, namely avoiding highest / maximum rate.

Provide benefits to employees in the form of money or cash and pleasure (Fringe Benefit) could be one option for avoid maximum tarif layers (shif to lower bracket). Because on essentially giving in kind and enjoyment (fringe benefits) can be deducted as a fee by the employer throughout the administration these are calculated as income taxed for employee who receives it. 
Selection of inventory valuation methods. There are two valuation methods allowed by tax regulations, the method of the mean (average) and first entry first method (first in first out). In conditioneconomies tend to have inflation, averaging method (average) will result in a higher cost than the method first entry first ( first in first out ). The higher cost of goods sold (HPP) will result in smaller gross profit.

For funding, fixed assets can consider leasing with option rights (finance lease ) in addition to direct purchases due to the term lease time is generally shorter than the age of assets and payments leasing can be fully covered. Thus, these assets can be financed faster than through depreciation if the purchase done directly.

Through the selection of allowable depreciation methods applicable taxation. If the company has a profit prediction large enough, it can be used accelerated depreciation method (balance decrease) so that the depreciation costs can reduce profits taxable and vice versa if estimated at the beginning of the investment year yet can give a profit or loss, the choice is use a depreciation method that provides a smaller cost (straight line) so that depreciation costs can be delayed for the following year.

Avoid tax imposition by directing to transactions that are not tax objects.

Optimizing tax credits per person, for this taxpayer must be observant to obtain information regarding the payment of taxes can be credited.

Delays in payment of tax obligations can be done in a way make payment when it approaches the due date. Special to postpone VAT payments can be done by delaying issuance of tax invoices up to the specified time limit on credit sales. The company can issue tax invoices on end of delivery month (Director General of Taxes No: 53 / PJ / 1994).

Avoid tax audits, tax inspection by the Directorate General tax is carried out on taxpayers who:

a. SPT is overpaid;

b. SPT loss;

c. Did not enter SPT or was late in submitting SPT;

d. There is information on violations;

e. Meet certain criteria set by the Director General of Taxes;

f. Avoiding overpayments can be done by:

1) Submitting a reduction in lump sum payments (installment period) PPh Article 25 to the relevant CTF, if estimated in years current tax will be overpaid taxes;

2) Submitting an importation request for Article 22 of PPh if the company imports.

g. Avoid violations of applicable tax regulations.

\section{RESULTS AND DISCUSSION}

In the current Indonesian tax laws and regulations, there is no clear definition of tax planning, aggressive tax planning, acceptable tax avoidance and unacceptable tax avoidance. Thus, in practice it often leads to different interpretations between taxpayers and tax officials. From the Taxpayer's point of view, it would certainly be argued that as long as the tax avoidance schemes that they do are not prohibited in tax laws and regulations, they are certainly considered legal. On the other hand, the government certainly also has an interest that not a tax provision is misused by taxpayers for the sole purpose of taxation that is detrimental to state revenues. Therefore for legal certainty for both taxpayers and the government, provisions regarding tax planning, tax avoidance, and anti tax avoidance in the form of Specific Avoidance Rule (SAAR) and General Anti Avoidance Rule (GAAR) must be clearly and detailed in the provisions tax laws and regulations, both for formal provisions, which are related to sanctions, as well as in the material provisions.

Many people both personally and in groups feel reluctant to pay taxes. This reluctance may be due to the lack of direct counter-performance given due to the payment, it could also be because the tax is considered by them as a burden so there are efforts to reduce it. For large companies, managing a minimum amount of tax will be very beneficial for them, because there is cash flow. 
Tax planning aggressive ones are very dangerous and can erode the tax base. The taxation system in Indonesia that is now being used is a development of the system that was originally carried out since the development of the manufacturing industry. Tax planning is a legal effort that can be done by taxpayers. The action is legal because tax savings are only done by using loopholes. Plans to minimizetax can be taken, for example, taking the maximum possible provisions from the provisions regarding exclusion and allowable deductions or deductions. In general, tax planning is to minimize tax obligations. Plans to minimize taxes can be taken by means of taking maximum advantage of the provisions regarding exceptions and allowances or deductions that are permissible, this can utilize income excluded as tax objects in accordance with article 4 paragraph 3.

Tax planning types can be divided as follow.

Domestic Tax Planning (national Tax Planning). National tax planning only pays attention to the Domestic Law, the election is carried out or not a transaction in the national tax planning depends on the transaction, meaning to avoid / reduce taxes, taxpayers can choose what types of transactions must be carried out in accordance with existing tax laws, for example, it will be subject to final special tax rates or not

International Tax Planning. International tax planning in addition to paying attention to the Domestic Law, must also pay attention to the law or tax treaty from the countries involved.

While the strategy can be used in tax planning can be divided as follow.

Tax saving. Efforts to streamline the tax burden through the selection of alternative taxation at a lower rate. Ex: In general giving to employees is generally not permitted to be charged as a cost in calculating corporate income tax. The natural granting policy can be converted into non-natural gifts and included as employee income so that it can be deducted as a fee. This treatment will result in the corporate income tax decreasing, but Article 21 Income Tax increases. Decrease in corporate income tax will be greater than the increase in Income Tax Article 21 (assuming the company gets taxable income above Rp. 100 million and corporate income tax is not final).

Tax avoidance. tax avoidance carried out by taxpayers by alleviating the tax burden / avoiding taxes legally (not violating the law) by utilizing loopholes contained in tax laws and regulations. Such as avoiding the imposition of taxes instead of tax objects.

Delaying Payment of Taxes. Delays in paying taxes can be done without breaking the rules. Example: To postpone VAT payments can be done by delaying the issuance of tax invoices until the allowable time limit, especially for credit sales, because the seller can issue tax invoices at the end of the following month after the tax submission month.

Optimizing Allowable Tax Credit. Taxpayers often lack information about payments that can be credited. For example: Article 22 Income Tax for the purchase of diesel fuel from Pertamina which is final if the buyer of the company is engaged in oil and gas distribution. But if the buyer is engaged in manufacturing, the Article 22 Income Tax can be credited with the corporate income tax. Crediting is more profitable than being charged as a fee. When compared, the profits obtained are equal to $75 \%$ of the value of the tax credited (for corporate taxable income above 2008). If credited, then all tax amounts are claimed by the taxpayer.However, if it is charged as a cost, the impact of the tax deduction is only $23 \%$, assuming that the cost is deductible expenses (deductible costs).

Avoiding Tax Audits by Avoiding More Pay. Submitting a reduction in the payment of installments to Article $25 \mathrm{PPh}$ concerned, if based on the estimation in the tax year concerned there will be an overpayment of tax. The submission can be done at the latest 3 months after the tax year has passed and the taxpayer can show that the income tax payable for the tax year is less than $75 \%$ of the income tax payable as the basis for calculating the amount of Income Tax Article 25.

So that it can be concluded that tax planning is useful:

- In order for the calculation of taxes or taxes to be paid by the taxpayer right or in accordance with the applicable tax regulations so that if research or inspection is carried out by the tax office there is no tax that has to be paid again and does not cause tax penalties for taxpayers; 
- In order for taxes to be paid by taxpayers to be smaller, it is done by using the loopholes in the tax regulations without violating existing tax regulations. To realize a tax planning that does not violate tax regulations, it is necessary to understand the tax regulations themselves, because the tax regulations that make people possible there are loopholes in regulations that can be used by taxpayers to avoid taxes without violating the law.

\section{CONCLUSION}

Tax planning (tax planning) refers to the reverse process and transaction business taxpayer that the tax debt is in minimal amounts, but still within the framework of tax regulations. However, tax planning can also be interpreted as planning the fulfillment of tax obligations in a complete, correct and timely manner so that they can optimally avoid waste of resources. Tax planning is the first step in tax management. Tax management itself is a means to fulfill tax obligations correctly, but the amount of tax paid can be reduced to a minimum to obtain the expected profit and liquidity. The next step is the implementation of tax implementation and tax control. At this stage of tax planning, collection and research on tax regulations is carried out. The aim is to be able to choose the type of tax saving measures that will be carried out. In general, the emphasis on tax planning is to minimize tax obligations.

\section{REFERENCES}

1. Adawiah, Diyah. 2011. Analisis Penerapan Perencanaan Pajak atas Biaya Kesejahteraan Karyawan pada Yayasan Al - Muhajirin Kota Depok. Jurusan Akuntansi Fakulttas Ekonomi and Bisnis Universitas Islam Negeri Syarif Hidayatullah: Jakarta.

2. Ahmadi. 2006. Perlindungan Hukum Bagi Wajib Pajak Dalam Penyelesaian Sengketa Pajak. Cet.1. Bandung: PT. Refika Aditama.

3. Brotodihardjo R. Santoso (1993), Pengantar Ilmu Hukum Pajak, 3rd ed, Bandung:PT Eresco.

4. Cao, Hongceng \& Xiaohui Xu. 2009. Study on The Tax Planning Enterprise Income Tax. International Journal of Business and Management, 4(5), Mei 2009.

5. Chen, S., Chen, X., Cheng, $Q$ and Shevlin, T. 2010. "Are Family Firms More Tax Aggresive than Non-Family Firms?" Journal of Financial Economics. 95: 41-61.

6. Damayanti. 2009. Perpajakan Indonesia - Mekanisme dan. Perhitungan. Edisi ke-l. Yogyakarta: ANDI.

7. Jensen, M. C. and Meckling, W. H. 1976. "Theory of the Firm: Managerial Behaviour, Agency Cost, and Ownership Structure". Journal of Financial Economics. 3(4): 305-360.

8. Mclaren, John. 2008. The Distinction Between Tax Avoidance and Tax Evasion has Become Blurred in Australia: Why has it Happened?. Journal of the Australasian Tax Teachers Association, 3(2), pp: 141-163.

9. Pohan, A. C. 2011. Kajian Perpajakan and Tax Planning-nya Terkini. Jakarta: Bumi Aksara.

10. Potas, Ivan. 1993. Thinking about Tax Avoidance. Trends and Issues No. 43, Australian Institute of Criminology, Australia.

11. Scott, William, R. 2009. Financial Accounting Theory. International Edition. New Jersey: Prentice-Hall, Inc.

12. Suandy, Erly. 2011. Perencanaan Pajak. Jakarta: Salemba Empat.

13. Wilson, R. 2007. An Examination Of Corporate Tax Shelter Participants. Working paper. University of Washington Business School.

14. Zain, Mohammad. 2008. Manajemen perpajakan. Penerbit: Salemba Empat. 